\title{
Adenosine Triphosphatase Activity of Tritrichomonas foetus
}

\author{
By DAVID LLOYD,* DONALD G. LINDMARK AND MIKLÓS MÜLLER \\ The Rockefeller University, New York, New York 10021, U.S.A.
}

(Received 11 January 1979; revised 25 April 1979)

\begin{abstract}
Homogenates of Tritrichomonas foetus exhibited a $\mathrm{Mg}^{2+}$-dependent adenosine triphosphatase (ATPase) activity, with a pH optimum in Tris buffers of $8 \cdot 2$ to $8 \cdot 3$. The activity was not sensitive to oxygen. At high concentrations, quercetin and 4-chloro-7-nitrobenzofurazan inhibited ATPase activity in the cytoplasmic extract by 20 and $70 \%$, respectively, whereas oligomycin, venturicidin, triethyltin, leucinostatin, dibutylchloromethyltin chloride, spegazzinine, efrapeptin, citreoviridin and sodium azide had no effect and $N, N^{\prime}$-dicyclohexylcarbodi-imide stimulated the activity somewhat. The activity was localized in a population of small cytoplasmic particles which also contained an acid phosphatase. There was no indication of an association of ATPase with hydrogenosomes. The ATPase activity (or activities) in this aerotolerant anaerobe is different from the ATPases characteristic of mitochondria or of anaerobic bacteria.
\end{abstract}

\section{INTRODUCTION}

Flagellate protozoa of the order Trichomonadida are parasitic aerotolerant anaerobes. Those species that have been studied are distinct from aerobic eukaryotes in that they have no cytologically recognizable mitochondria (Brugerolle, 1972; Daniel et al., 1971; Honigberg et al., 1971; Honigberg, 1978) and no detestable cytochromes (Ryley, 1955; Čerkasovová, 1970; Lloyd et al., 1979), and they do not carry out oxidative phosphorylation (Čerkasov et al., 1978; Müller \& Lindmark, 1978). The major organelle of their energy metabolism is the hydrogenosome which produces $\mathrm{H}_{2}$ under anaerobic conditions (Lindmark \& Müller, 1973; Lindmark et al., 1975) and acts as a respiratory organelle in the presence of $\mathrm{O}_{2}$ (Čerkasov et al., 1978; Müller \& Lindmark, 1978). The biological nature and affinities of this organelle are poorly understood. Since adenosine triphosphatases (ATPases) of different organelles and micro-organisms show characteristic properties, it was felt that a study of the ATPase activities present in a trichomonad could contribute to the elucidation of the biological nature of hydrogenosomes.

This paper reports some of the properties of the ATPase in Tritrichomonas foetus. No inhibitor binding sites characteristic of mitochondrial ATPase nor the presence of an ATPase similar to that found in Clostridium pasteurianum (Clarke \& Morris, 1976, 1977) could be detected. The ATPase is not localized in the hydrogenosomes but in a population of small particles which were described earlier as organelles containing certain acid hydrolases (Müller, 1973).

\section{METHODS}

Maintenance, growth and harvesting of the organism. Tritrichomonas foetus $\mathrm{KV}_{1}$ (obtained from $\mathrm{Dr}$ B. M. Honigberg) was cultured in Diamond's liquid TYM medium without agar, supplemented with $10 \%$ (v/v) heat-inactivated horse serum (Diamond, 1957). Stock cultures were subcultured daily and used to inoculate 400 or $800 \mathrm{ml}$ of culture medium (in 500 or $1000 \mathrm{ml}$ Erlenmeyer flasks closed with screw caps).

* Permanent address: Department of Microbiology, University College, Newport Road, Cardiff CF2 1TA. 
Cultures were grown for $24 \mathrm{~h}$ at $37^{\circ} \mathrm{C}$ and harvested when the population reached $1 \times 10^{6}$ to $2 \times 10^{6}$ organisms $\mathrm{ml}^{-1}$ (Müller, 1973). Organisms were harvested at room temperature in a Sorvall RC-3 centrifuge (GS-3 rotor; $500 \mathrm{ml}$ bottles) at $1000 \mathrm{~g}_{\text {av }}$. for $5 \mathrm{~min}$, and then washed three times in $50 \mathrm{~mm}-\mathrm{Tris} / \mathrm{H}_{2} \mathrm{SO}_{4}$ buffer $(\mathrm{pH} \mathrm{6.7)} \mathrm{at} \mathrm{room} \mathrm{temperature.}$

Preparation of cell extracts and subcellular fractionation. Organisms were resuspended in 3 vol. ice-cold $50 \mathrm{~mm}$-Tris $/ \mathrm{H}_{2} \mathrm{SO}_{4}$ buffer or in unbuffered $250 \mathrm{~mm}$-sucrose. Cells were broken with 20 to 30 strokes in a Potter-Elvehjem tissue homogenizer fitted with a smooth Teflon pestle rotating at $1000 \mathrm{rev}$. $\mathrm{min}^{-1}$. Whole cells and nuclei were sedimented in a Sorvall RC-2B refrigerated centrifuge (SS-34 rotor) at $400 \mathrm{~g}_{\text {av. }}$ for $4 \mathrm{~min}$ and the supernatant (termed the cytoplasmic extract) was carefully decanted. In certain experiments rigorous precautions were taken to maintain anaerobiosis during the harvesting and disruption of organisms and subsequent preparation of homogenates, by bubbling argon through all buffers and by the inclusion of $150 \mathrm{~mm}$-2-mercaptoethanol.

For cell fractionation studies the cells were resuspended in $250 \mathrm{~mm}$-sucrose and broken by the procedure described above. Differential centrifugation, as previously described (Lindmark \& Müller, 1973), yielded four fractions: a nuclear fraction (N, at $1600 \mathrm{~g}$-min), a large particle fraction $\left(\mathrm{P}_{1}\right.$, at $3.6 \times 10^{4} \mathrm{~g}$-min), a small particle fraction $\left(\mathrm{P}_{2}\right.$, at $7.2 \times 10^{5} \mathrm{~g}$-min), and a final supernatant (S). In one experiment the large and the small particle fractions were subfractionated by isopycnic centrifugation in a sucrose gradient using the Beaufay rotor (Leighton et al., 1968). The methods used and the representation of the results were described earlier (Müller, 1973).

Enzyme assays. ATPase (EC 3.6.1.3) was assayed by incubating extracts in a mixture containing $50 \mathrm{~mm}-$ Tris $/ \mathrm{H}_{2} \mathrm{SO}_{4}$ buffer, $2 \mathrm{~mm}-\mathrm{ATP}$ and $6 \mathrm{mM}-\mathrm{MgSO}_{4}$ at $\mathrm{pH} 8.3$ in a total volume of $1 \mathrm{ml}$ at $30^{\circ} \mathrm{C}$. After the reaction had been stopped by adding $100 \mu \mathrm{l}$ of $50 \%$ (w/v) trichloroacetic acid, the protein precipitate was sedimented by centrifugation and $\mathrm{P}_{\mathrm{i}}$ was determined in the supernatant fluid by the method of Fiske $\&$ SubbaRow (Leloir \& Cardini, 1957). Corrections for enzyme and substrate blanks were made as a routine and results are mean values from triplicate determinations (S.D. $< \pm 3 \%$ ). In experiments where the effect of freezing and thawing and of detergents on the activity was studied, the cytoplasmic particles were osmotically protected by inclusion of $250 \mathrm{~mm}$-sucrose in all solutions. Assays for acid phosphatase (EC 3.1.3.2) using $p$-nitrophenylphosphate as substrate, $\beta$ - $N$-acetylglucosaminidase (EC 3.2.1.30), NADH dehydrogenase (NADH:oxygen oxidoreductase) and malate dehydrogenase (decarboxylating) were as previously described (Müller, 1973; Lindmark \& Müller, 1973). Protein was determined by an automated Lowry procedure with bovine serum albumin as standard (Leighton et al., 1968). Enzyme units (U) are defined as the amount of enzyme necessary to release $1 \mu \mathrm{mol}$ product $\mathrm{min}^{-1}$ under the assay conditions.

Chemicals. ATP (disodium salt), oligomycin and quercetin (3,3',4',5,7-pentahydroxyflavone) were from Sigma; citreoviridin from Cambrian Chemicals, Beddington Farm Road, Croydon; $N, N^{\prime}$-dicyclohexylcarbodi-imide and venturicidin from $\mathrm{BDH}$; 4-chloro-7-nitrobenzofurazan ( $\mathrm{Nbf}-\mathrm{Cl}$ ) from Aldrich Chemical Co., Wembley, Middx; efrapeptin (antibiotic A23871) and leucinostatin from Dr R. Hamill, Lilly Research Laboratories, Minneapolis, Minn., U.S.A.; triethyltin sulphate and dibutylchloromethyltin chloride from Dr D. E. Griffiths, Department of Molecular Sciences, University of Warwick, Coventry; and spegazzinine, a dihydroindole alkaloid, from Division de Quimica Organica Superior, Universidad National de la Plata, La Plata, Argentina. All inhibitors were dissolved in ethanol.

\section{RESULTS}

In Tris/maleate or Tris/ $\mathrm{H}_{2} \mathrm{SO}_{4}$ buffers the ATPase displayed optimum activity at $\mathrm{pH}$ $8 \cdot 2$ to $8 \cdot 3$. The specific activity of ATPase at the $\mathrm{pH}$ optimum in Tris $/ \mathrm{H}_{2} \mathrm{SO}_{4}$ at $30{ }^{\circ} \mathrm{C}$ was $25 \cdot 5 \pm 5 \cdot 6 \mathrm{mU}$ (mg protein) $)^{-1}$ (mean value \pm S.D. for determinations on six different extracts). The $\mathrm{pH}$ dependence and specific activity of the enzyme were not altered if the homogenates were prepared under anaerobic conditions in the presence of 2-mercaptoethanol. The enzyme was $\mathrm{Mg}^{2+}$-dependent. Replacement of $\mathrm{Mg}^{2+}$ by $\mathrm{Ca}^{2+}$ decreased activity to $64 \%$, and $\mathrm{Na}^{+}$ or $\mathrm{K}^{+}$, added singly or together, gave less than $17 \%$ of the activity observed with $\mathrm{Mg}^{2+}$ (Table 1).

Of the 12 compounds tested as ATPase inhibitors, only Nbf-Cl and quercetin gave significant inhibition (Table 2). The concentrations used were greatly in excess of the $I_{50}$ values previously determined for the mitochondrial ATPase of yeast (Lloyd \& Edwards, 1976, 1977). At the optimum $\mathrm{pH}, N, N^{\prime}$-dicylohexylcarbodi-imide [20 $\mu \mathrm{g}$ (mg protein) $\left.{ }^{-1}\right]$ stimulated activity by $21 \%$ whereas slight inhibition was observed at $\mathrm{pH}$ values below $6 \cdot 3$.

Activity of ATPase of cytoplasmic extracts prepared in $250 \mathrm{~mm}$-sucrose was increased 
Table 1. Effect of cations on ATPase activity of $T$. foetus

A cytoplasmic extract was dialysed for $24 \mathrm{~h}$ against $50 \mathrm{~mm}$-Tris/ $\mathrm{HCl}$ buffer (pH 8.7 ) in $250 \mathrm{~mm}$ sucrose. The assay for ATPase was as described in Methods except that Tris/HCl was used instead of Tris $/ \mathrm{H}_{2} \mathrm{SO}_{4}$ buffer. Cations or EDTA were added at $20 \mathrm{mM}$.

$\begin{array}{lc}\text { Addition } & \begin{array}{c}\text { Relative } \\ \text { activity }\end{array} \\ \text { None } & 8 \\ \text { EDTA } & 4 \\ \mathrm{Mg}^{2+} & 100 \\ \mathrm{Ca}^{2+} & 64 \\ \mathrm{~K}^{+} & 17 \\ \mathrm{Na}^{+} & 13 \\ \mathrm{~K}^{+}+\mathrm{Na}^{+} & 14\end{array}$

Table 2. Effect of inhibitors on ATPase activity of a cytoplasmic extract of $T$. foetus Inhibitors dissolved in ethanol were added to the enzyme preparation and pre-incubated for $10 \mathrm{~min}$ before starting the reaction. The specific activity of the extract was $33 \mathrm{mU}$ (mg protein)-1. Tests and controls contained $2 \%(\mathrm{v} / \mathrm{v})$ ethanol.

Inhibitor

$N, N^{\prime}$-Dicyclohexylcarbodi-imide

Oligomycin

Venturicidin

Triethyltin sulphate

Leucinostatin

Dibutylchloromethyltin chloride

Spegazzinine

Quercetin

Efrapeptin

$\mathrm{Nbf}-\mathrm{Cl}$

Citreoviridin

Sodium azide (in $\mathrm{H}_{2} \mathrm{O}$ )

\begin{tabular}{|c|c|}
\hline $\begin{array}{c}\text { Concn }[\mu \mathrm{g} \\
\left.(\mathrm{mg} \text { protein })^{-1}\right]\end{array}$ & $\begin{array}{l}\text { Activity } \\
\text { (\% of } \\
\text { control) }\end{array}$ \\
\hline 72 & 132 \\
\hline 182 & 94 \\
\hline 36 & 104 \\
\hline 36 & 92 \\
\hline 36 & 107 \\
\hline 72 & 99 \\
\hline 18 & 95 \\
\hline 182 & 82 \\
\hline 36 & 103 \\
\hline 182 & 23 \\
\hline 18 & 104 \\
\hline $2 \mathrm{mM}$ & 93 \\
\hline
\end{tabular}

Activity

ontrol)

94

104

107

99

82

103

104

93

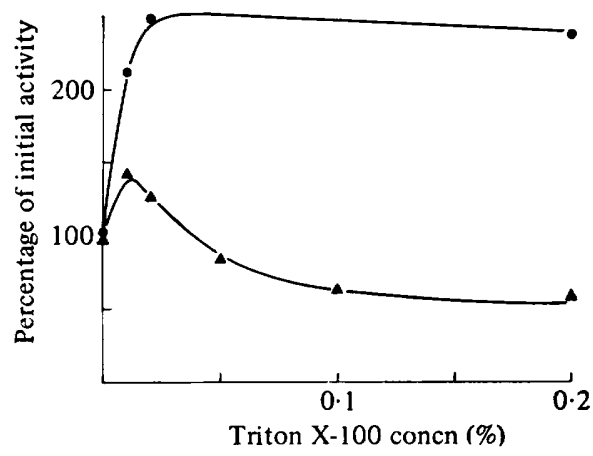

Fig. 1. Effect of Triton X-100 on activities of ATPase $(\boldsymbol{\Delta})$ and acid phosphatase (O) in cytoplasmic extracts of $T$. foetus. The final concentration of protein in the assay was $490 \mu \mathrm{g} \mathrm{ml}^{-1}$.

by about $20 \%$ by three cycles of freezing and thawing, without any further increase if the procedure was repeated up to 15 cycles. A $50 \%$ increase of activity was observed in the presence of low concentrations [200 $\mu \mathrm{g}$ (mg protein) ${ }^{-1}$ ] of the non-ionic detergent Triton $\mathrm{X}-100$, but larger amounts of the detergent elicited a significant decrease in activity (Fig. 1). Acid phosphatase activity similarly was not unmasked fully by freezing and thawing, but could be fully activated by Triton X-100 at $\geqslant 500 \mu \mathrm{g}$ (mg protein) $)^{-1}$.

The distributions of malate dehydrogenase (decarboxylating), a marker enzyme for 


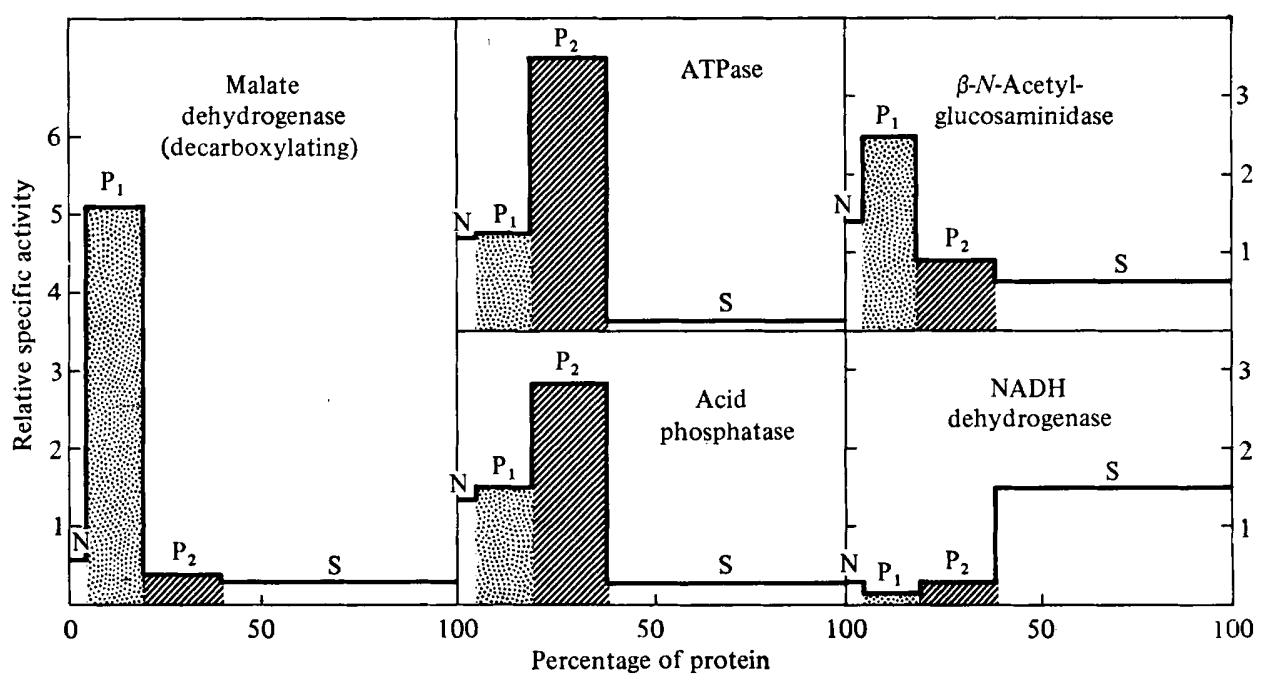

Fig. 2. Distribution of enzymes in a homogenate of $T$. foetus after differential centrifugation. Relative specific activities of the enzymes are plotted against the cumulative percentage of protein recovered in each fraction. The direction from left to right corresponds to increasing centrifugal field. The left-hand block $(\mathrm{N})$ of each histogram represents the nuclear fraction and the right-hand block represents the final supernatant (S). The large particle fraction $\left(\mathrm{P}_{1} ;\right.$ stippled) and the small particle fraction $\left(\mathbf{P}_{\mathbf{2}}\right.$; shaded) were subfractionated by isopycnic centrifugation (Fig. 3 ). Percentage recoveries: ATPase (114), acid phosphatase (95), $\beta$ - $N$-acetylglucosaminidase (59), malate dehydrogenase (decarboxylating) (80), NADH dehydrogenase (84) and protein (74).

hydrogenosomes (Müller, 1973; Lindmark \& Müller, 1973), and of acid phosphatase and $\beta$ - $N$-acetylglucosaminidase, markers for the smaller and larger hydrolase-containing particles, respectively, showed, after either the differential (Fig. 2) or isopycnic (Fig. 3) centrifugation, distributions similar to those reported earlier (Müller, 1973). Over $90 \%$ of the NADH dehydrogenase was associated with the final supernatant, indicating a low contamination of the particulate fractions with the non-sedimentable portion of the cytoplasm. More than $90 \%$ of the total ATPase was associated with the particulate fractions, with highest relative specific activity in the small particle fraction (Fig. 2). The distribution patterns of ATPase observed after differential (Fig. 2) and isopycnic (Fig. 3) centrifugation were similar to those of acid phosphatase, suggesting that the major subcellular site of these two enzymes is a well-defined population of hydrolase-containing smaller particles. No evidence could be found for an association of ATPase with hydrogenosomes. Isopycnic centrifugation clearly separated from the hydrogenosomes the ATPase activity recovered in the large particle fraction after differential centrifugation.

Although the fractionation results did not suggest the association of ATPase with hydrogenosomes, the properties of the enzymic activity observed in the large particle fraction were studied to obtain further information on the possibility of an ATPase being present in these organelles. The optimum $\mathrm{pH}$ value for ATPase in the large particle fraction, as in the cytoplasmic extracts, was $8 \cdot 3$; stimulation of activity was observed when $N, N^{\prime}$-dicyclohexylcarbodi-imide $\left[95 \mu \mathrm{g}(\mathrm{mg} \text { protein })^{-1}\right.$ ] was included in the assay at all $\mathrm{pH}$ values between $5 \cdot 2$ and 8.6. Quercetin [240 $\mu \mathrm{g}$ (mg protein) ${ }^{-1}$ ] gave up to $59 \%$ inhibition over this $\mathrm{pH}$ range; azide had no effect. At $\mathrm{pH} 8 \cdot 3, \mathrm{Nbf}-\mathrm{Cl}\left[450 \mu \mathrm{g}(\mathrm{mg} \text { protein })^{-1}\right]$ gave $70 \%$ inhibition and triethyltin sulphate [ $90 \mu \mathrm{g}$ (mg protein) ${ }^{-1}$ ] $50 \%$ inhibition. All other compounds tested with ATPase activity of cytoplasmic extracts were without significant inhibitory effect on the ATPase activity of the large particle fraction. $N, N^{\prime}$-Dicyclohexylcarbodi-imide [up to $95 \mu \mathrm{g}$ (mg protein $)^{-1}$ ] did not inhibit ATPase in any of the fractions. 


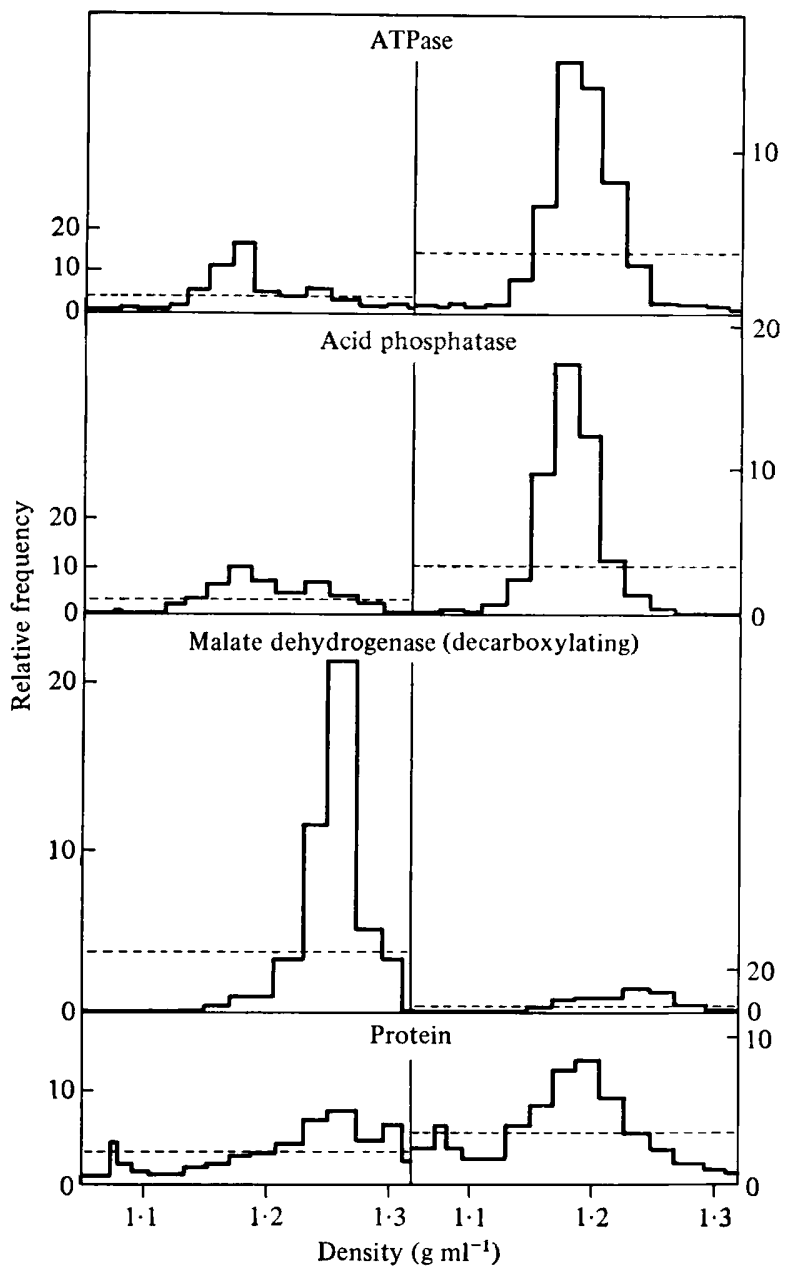

Fig. 3. Distribution of enzymes after isopycnic centrifugation of the large particle fraction (left) and the small particle fraction (right) represented in Fig. 2 by the stippled and shaded areas, respectively. Density-frequency plots are shown. The scales of the ordinates have been adjusted so that the area under each histogram is proportional to the percentage of total enzyme activity present in the particle fractions used as starting material; however, the ordinate has been expanded threefold for protein, to improve clarity. The dashed lines represent the relative frequencies of components distributed uniformly through the gradients; they therefore delimit areas equal to those of the corresponding histograms. Relative frequency is given by the equation (de Duve, 1967):

Relative frequency $=\frac{\text { Enzyme units in a fraction }}{\text { Total enzyme units recovered }} \times \frac{1}{\text { Percentage density increment in that fraction }}$ Percentage recoveries for the two gradients: ATPase (116 and 75), acid phosphatase (76 and 107), malate dehydrogenase (decarboxylating) (65 and 78), protein (83 and 97).

\section{DISCUSSION}

Electron microscopy of $T$. foetus has revealed many different subcellular structures, but no organelles recognizable as mitochondria (Honigberg et al., 1971; Müller, 1973; Honigberg, 1978). The most conspicuous membrane-bounded organelles are the hydrogenosomes, the subcellular sites of pyruvate oxidation, which differ in several major characteristics from mitochondria (Müller, 1973; Lindmark \& Müller, 1973; Čerkasov et al., 1978; Müller \& Lindmark, 1978) but whose biological nature is not fully elucidated. It is now well 
established that some eukaryotic micro-organisms lack differentiated mitochondria under certain environmental conditions or in certain stages of their life cycle. This is observed in anaerobically grown, facultatively anaerobic yeasts and in the bloodstream forms of members of the Trypanosoma brucei group. However, these organisms still retain mitochondrial ATPase activity sensitive to oligomycin (Cartledge \& Lloyd, 1973; Opperdoes et al., 1977), to $N, N^{\prime}$-dicyclohexylcarbodi-imide (Cartledge \& Lloyd, 1973), as well as to a number of other mitochondrial ATPase inhibitors (T. G. Cartledge \& D. Lloyd, unpublished observations). In contrast to these organisms, the ATPase activity of $T$. foetus was inhibited only by $\mathrm{Nbf}-\mathrm{Cl}$ and quercetin, which, although potent inhibitors of the $\mathrm{F}_{1}$ portion of mitochondrial ATPase (Lloyd \& Edwards, 1977), are likely to be less specific in their action than the antibiotic inhibitors oligomycin, citreoviridin, leucinostatin and efrapeptin. Quercetin is also known to inhibit the $\mathrm{Na}^{+}, \mathrm{K}^{+}$-ATPase of plasma membranes (Racker, 1976). Mitochondrial ATPases from mammals, yeast (Lloyd \& Edwards, 1977) and from the protozoon Acanthamoeba castellanii (S. W. Edwards \& D. Lloyd, unpublished observations) all show similar sensitivities to inhibitors. Thus the present observations further confirm the absence from $T$. foetus of enzymes typical of the inner mitochondrial membrane (Lloyd et al., 1979).

The similarity between several of the reactions involved in the generation of $\mathrm{H}_{2}$ from pyruvate in $T$. foetus (Lindmark \& Müller, 1973) and in obligately anaerobic bacteria of the genus Clostridium (Uyeda \& Rabinowitz, 1971) has led to the speculation that the hydrogenosome may have evolutionary affinities with these prokaryotes. An oxygen-sensitive ATPase in C. pasteurianum has a transport function (Riebeling et al., 1975; Clarke \& Morris, 1977), and although the enzyme is not inhibited by a number of inhibitors, it is sensitive to inhibition by $N, N^{\prime}$-dicyclohexylcarbodi-imide and $\mathrm{Nbf-Cl}$ (Clarke \& Morris, 1976, 1977). Thus the ATPases of $T$. foetus do not include an enzyme resembling either the mitochondrial or clostridial enzymes in their inhibitor binding sites.

Our results demonstrate that there is no $\mathrm{Mg}^{2+}$-activated ATPase in the hydrogenosomes, suggesting that transport processes participating in the function of this organelle (Čerkasovová \& Čerkasov, 1976) are not linked directly to an ATP-dependent proton translocation mechanism.

The subcellular location of the ATPase of $T$. foetus was found to be the population of smaller subcellular particles, which have previously been shown to contain acid phosphatase and also $\beta$-glucuronidase, but which lack several other hydrolases that are confined to larger hydrolase-containing organelles in this organism (Müller, 1973). The functional role of these organelles and that of the trichomonad ATPase await further investigations.

We wish to thank Dr J. McLaughlin for stimulating discussion and Miss N. Dick and Mr D. Fishel for expert technical assistance. D. L. was Guest Investigator at The Rockefeller University (June to July 1978) and held a Leverhulme Travelling Fellowship. This research was supported by U.S. Public Health Service Grant AI11942 from the National Institute of Allergy and Infectious Diseases.

\section{REFERENCES}

Brugerolle, G. (1972). Characterisation ultrastructurale et cytochimique de 2 types de granules cytoplasmiques chez les Trichomonas. Protistologica 8, 352-363.

Cartledge, T. G. \& Lloyd, D. (1973). Changes in enzyme activities and distributions during glucose derepression and respiratory adaptation of anaerobically grown Saccharomyces carlsbergensis. Biochemical Journal 132, 609-621.

Cerkasov, J., Čerkasovová, A., Kulda, J. \& VILHELMOVÁ, D. (1978). Respiration of hydrogenosomes of Tritrichomonas foetus. I. ADP- dependent oxidation of malate and pyruvate. Journal of Biological Chemistry 253, 12071214.

Čerkasovová, A. (1970). Energy-producing metabolism of Tritrichomonas foetus. I. Evidence for control of intensity and the contribution of aerobiosis to total energy production. Experimental Parasitology 27, 165-178.

Čerkasovová, A. \& ČrkKasov, J. (1976). Some properties of the membrane of hydrogenosomes of Tritrichomonas foetus. In Biochemistry of Parasites and Host-Parasite Relationships, pp. 
23-30. Edited by H. Van den Bossche. Amsterdam: North-Holland Publishing Co.

Clarke, D. \& Morris, J. G. (1976). Partial purification of DCCD-sensitive membrane ATPase complex from the obligately-anaerobic bacterium Clostridium pasteurianum. Biochemical Journal 154, 725-729.

Clarke, D. \& MorRis, J. G. (1977). Reconstitution of a functional proton-translocating adenosine triphosphatase from the obligately-anaerobic bacterium Clostridium pasteurianum. Biochemical Society Transactions 5, 140-143.

Daniel, W. A., Mattern, C. F. T. \& Honigberg, B. M. (1971). Fine structure of the mastigont system in Tritrichomonas muris (Grassi). Journal of Protozoology 18, 575-586.

DiAMOND, L. S. (1957). The establishment of various trichomonads of animals and man in axenic cultures. Journal of Parasitology 43, 488-490.

DE DUVE, C. (1967). General principles. In Enzyme Cytology, pp. 1-26. Edited by D. B. Roodyn. New York: Academic Press.

HoNigBerg, B. M. (1978). Trichomonads of veterinary importance. In Parasitic Protozoa, vol. 2, pp. 163-273. Edited by J. P. Kreier. New York: Academic Press.

Honigberg, B. M., Mattern, C. F. T. \& Daniel, W. A. (1971). Fine structure of the mastigont system in Tritrichomonas foetus (Riedmüller). Journal of Protozoology 18, 183-198.

Leighton, F., Poole, B., Beaufay, H., Baudhuin, P., Coffey, J. W., Fowler, S. \& de Duve, C. (1968). The large-scale separation of peroxisomes, mitochondria, and lysosomes from the livers of rats injected with Triton WR-1339. Improved isolation procedures, automated analysis, biochemical and morphological properties of fractions. Journal of Cell Biology 37, 482-513.

Leloir, L. F. \& CARdINI, C. E. (1957). Characterization of phosphorus compounds by acid lability. Methods in Enzymology 3, 841-850.

LindmaRK, D. G. \& MülleR, M. (1973). Hydrogenosome, a cytoplasmic organelle of the anaerobic flagellate, Tritrichomonas foetus, and its role in pyruvate metabolism. Journal of Biological Chemistry 248, 7724-7728.

Lindmark, D. G., Mülller, M. \& Shio, H. (1975).
Hydrogenosomes in Trichomonas vaginalis. Journal of Parasitology 61, 552-554.

LlOYD, D. \& EDWARDS, S. W. (1976). Mitochondrial adenosine triphosphatase of the fission yeast Schizosaccharomyces pombe $972 \mathrm{~h}^{-}$. Changes in activity and inhibitor sensitivity in response to catabolite repression. Biochemical Journal 160, 335-342.

LlOYD, D. \& EDWARds, S. W. (1977). Mitochondrial adenosine triphosphatase of the fission yeast Schizosaccharomyces pombe $972 \mathrm{~h}^{-}$. Change in activity and inhibitor sensitivities during the cell cycle indicate similarities and differences in binding sites. Biochemical Journal 162, 581-590.

LlOYD, D., LindmaRK, D. G. \& Müller, M. (1979). Respiration of Tritrichomonas foetus: absence of detectable cytochromes. Journal of Parasitology 65, 466-469.

MülleR, M. (1973). Biochemical cytology of trichomonad flagellates. I. Subcellular localization of hydrolases, dehydrogenases, and catalase in Tritrichomonas foetus. Journal of Cell Biology 57, 453-474.

MÜLleR, M. \& LINDMARK, D. G. (1978). Respiration of hydrogenosomes in Tritrichomonas foetus. II. Effect of CoA on pyruvate oxidation. Journal of Biological Chemistry 253, 1215-1218.

Opperdoes, F. R., Borst, P. \& SpITs, H. (1977). Particle-bound enzymes in the bloodstream form of Trypanosoma brucei. European Journal of Biochemistry 76, 21-28.

RACKER, E. (1976). In A New Look at Mechanisms in Bioenergetics, p. 168. New York: Academic Press.

Riebeling, V., Thauer, R. K. \& JungermanN, K. (1975). The internal-alkaline $\mathrm{pH}$ gradient sensitive to uncoupler and ATPase inhibitor, in growing Clostridium pasteurianum. European Journal of Biochemistry 55, 445-453.

RYLEY, J. F. (1955). Studies on the metabolism of the protozoa. 5. Metabolism of the parasitic flagellate Trichomonas foetus. Biochemical Journal 59, 361-363.

Uyeda, K. \& Rabinowitz, J. G. (1971). Pyruvateferredoxin oxidoreductase of Clostridium acidiurici. Journal of Biological Chemistry 246, 31113119 . 